удК 349.42

\title{
О.И. Козлова
}

\section{ЭКОНОМИЧЕСКОЕ РАЗВИТИЕ АГРАРНОГО СЕКТОРА: АКТУАЛЬНЫЕ ПЕРСПЕКТИВЫ СОВЕРШЕНСТВОВАНИЯ ЗАКОНОДАТЕЛЬСТВА}

Актуальность темы. В современных условиях хозяйствования аграрный сектор экономики выступает одним из ключевых факторов экономического развития государства, который, помимо обеспечения налоговых поступлений и прибыли в государственную казну, так же является главным сегментом обеспечения продовольственной безопасности. В то же время, аграрный сектор выполняет важнейшую роль в социально-экономическом развитии государства, обеспечивая продовольствием и продуктами питания население страны и создавая социальную инфраструктуру в сельской местности. Вместе с этим, очевидным является тот факт, что развитие аграрного сектора напрямую зависит от государственной аграрной политики, которая основывается на управлении и регулировании отношений в сфере производства и реализации аграрной продукции. Необходимо отметить, что данные составляющие регуляторной политики основываются на использовании эффективных инструментов государственного влияния на сферу агропромышленного комплекса (далее - АПК), где административно-правовые нормы играют главенствующую роль, поскольку создают непосредственный инструментарий, формирующий режим функционирования субъектов хозяйствования АПК. Поэтому актуальной научной проблемой является исследование путей усовершенствования законодательства данной сферы общественных отношений, что в сравнительном разрезе правового регулирования в государствах может стать почвой для поиска эффективных решений.

Состояние научной разработки проблемы. Исследование в сфере правового регулирования экономического развития аграрного сектора широко проводятся как украинскими, так и российскими, а так же и зарубежными учеными. Из последних научных работ стоит отметить таких авторов, как И.В. Бабабян, Л.М. Васильева, Е.А. Городецкая, А.В. Жемойда, А.В. Ключник, И.П. Кузьмич, К.Н. Назаренко, О.Н. Сомойлова, Д.Н. Тамбовцев, Н.М. Ткаченко, Ф.М. Топсахалова и других. В то же время недостаточно исследованными остаются сравнительно-правовые аспекты правового регулирования экономического развития АПК в условиях поиска путей совершенствования законодательства.

Цель и задачи статьи. Целью статьи является проведение сравнительно-правового анализа законодательного обеспечения экономического развития АПК в Украине и Российской Федерации. Задачей статьи является поиск рекомендаций совершенствования механизмов и направлений государственного регулирования функционирования предприятий АПК в указанных государствах.

Основной материал. На данный момент в Украине основной задачей совершенствования сельскохозяйственных производственных стандартов в соответствии с нормами международных соглашений является достижение необходимых условий, обеспечивающих пищевую безопасность экспортируемой Украиной аграрной продукции. В этом направлении украинское законодательство идет по пути 
ужесточения регламентных требований к производству, источником такой политики выступает Глава 17 Соглашения об ассоциации с государствами ЕС [1], которая предусматривает имплементацию европейских и международных стандартов безопасности и качества продуктов питания и сельскохозяйственной продукции, среди которых такие стандарты, как HACCP, ISO, EN, Кодекс Алиментариус. Указанные положения Соглашения об ассоциации направлены на стимулирование развития украинского законодательства в направлении регламентации улучшения качества аграрной продукции путем повышения стандартов выпуска продукции, требований к экологизации производства и нормативных схем качества.

Вся сложность усовершенствования украинского административно-правового регулирования сферы АПК в указанном направлении состоит в том, что для реализации описанных требований в украинское законодательство необходимо имплементировать требования директив и регламентов ЕС, а так же почти все действующие европейские стандарты относительно сельского хозяйства и пищевой промышленности. На современном этапе украинское законодательство имплементировало большую часть данных стандартов, среди которых абсолютное выполнение реализовано в направлении табачной промышленности.

Необходимо отметить, что имплементация европейских стандартов и регламентов в Украине, на наш взгляд, должна быть построена на пересмотре всех устаревших стандартов - ГОСТов, значительная часть которых и на данный момент регулирует производство аграрной продукции. Гармонизация стандартов в этой сфере должна базироваться на постоянном мониторинге нововведений в стандартах ЕC, например таких, как ISO, IEC, CEN, CENELEC. Так же важным следует отметить тот факт, что для повышения качества импортируемых товаров в украинском законодательстве необходимо предусмотреть нормы европейских стандартов, которые регулируют качество сельскохозяйственной продукции.

Следует отметить, что украинская законодательная практика по внедрению административно-правовых условий Европейского союза (далее - ЕС) в стандарты аграрного производства для эффективной реализации требует должного институционального обеспечения. С этой целью считаем необходимым создать в составе Министерства аграрной политики и продовольствия Украины единый орган по контролю безопасности производства пищевых продуктов и обеспечения системы санитарии и гигиены. На наш взгляд, эффективная работа данного органа может базироваться на последовательной гармонизованной с нормами ЕС административно-правовой системе регулирования безопасности производства пищевой продукции. Главным законодательным решением в этой сфере может стать утверждение национальных соответствий стандартам ISO серии 22000.

В Российской Федерации одним из самых актуальных аспектов административноправового регулирования данной сферы общественных отношений выступает совершенствование условий внешнеэкономической деятельности субъектов хозяйствования АПК. Главным аспектом совершенствования административно-правового регулирования здесь мы выделяем усиление фитосанитарных норм не ниже норм ЕС и стандартизацию безопасности продуктов питания не ниже уровня норм НАССР для производителей продукции АПК, которая экспортируется. Данная позиция 
связанна с тем, что основная продукция экспорта - зерновые и другие виды давальческого сырья квотируются в экспортной деятельности, что связанно с продовольственной безопасностью страны. В то же время, повышение стандартов и фитосанитарных норм конечной аграрной продукции сможет вывести российский аграрный экспорт на более широкий уровень потребления, не ограничиваясь странами Таможенного соглашения. В системе стимулирования технической реализации усиления фитосанитарных норм и других стандартов качества производства ключевую роль должен играть административно-финансовый механизм возмещения части затрат на закупку перерабатывающего оборудования и других технических средств. Возмещение части затрат так же может производиться путем предоставления налоговых каникул предприятиям, реализующим инновационные технологии, направленные на обеспечение надлежащих стандартов производства продукции, предназначенной для экспортных целей.

Помимо этого, в Российской Федерации финансовая поддержка предприятий АПК выступает одним из главных направлений государственного регулирования отношений в данной сфере. В этом направлении важно сформировать оптимальные административно-правовые условия для эффективной политики государства в сфере финансирования, кредитования, субсидирования и дотирования предприятий комплекса. Важнейшим направлением здесь выступает формирование оптимальной налоговой политики, формирование порядка администрирования налоговых платежей на всех уровнях на принципах налоговых стимулов и налоговых каникул для субъектов хозяйствования.

Государственная поддержка АПК в районах Крайнего Севера и приравненных к ним территориях должна быть построена на приоритетности финансирования, налогообложения, субсидирования и других административно-финансовых элементов, описанных выше. В то же время, важно учесть, что поддержка на подобных принципах и основах агропредприятий указанных территорий должна совершаться только при наличии фактического местонахождения основных средств производства, невзирая на место регистрации предприятия, что исключит потенциальную возможность злоупотреблений.

Не менее важным направлением считаем страхование хозяйственной деятельности предприятий АПК, которое требует отдельного урегулирования, поскольку данный инструмент в перспективе должен стать общеобязательной нормой, важным направлением его развития может стать положение, создающее административно-правовые условия для участия в страховании продуктов хозяйствования агропредприятий иностранными страховыми компаниями, что так же привлечет дополнительные налоговые поступления в федеральный бюджет РФ.

В связи с этим Назаренко К.Н. справедливо отмечает, что в современных условиях страхование является одним из основных способов управления рисками. Используя страхование, предприниматель трансформирует риск с малой вероятностью наступления, но с катастрофическими потерями, в необходимость нести относительно незначительные издержки в виде страховых взносов. При этом потенциальный страховой интерес предпринимателей связан с получением покрытия по максимальному количеству рисков. На основе изучения отечественной и зарубежной литературы 
можно утверждать, что страхование и предпринимательство тесно взаимосвязаны. Для предпринимательства характерны организационно-хозяйственное новаторство, поиск новых, более эффективных способов использования ресурсов, гибкость, готовность идти на риск. Используя инструмент страхования, предприниматель уверен, что средства производства, продукция, финансовые ресурсы материально защищены от случайностей, и получает возможность сосредоточить все свое внимание на проблемах, непосредственно связанных с производственной деятельностью. Сущность страхования в АПК состоит в том, что потребители услуги (страхователи) приобретают за определенную плату (страховой взнос) гарантию возмещения возможного ущерба за счет перераспределения объема ущерба немногих пострадавших среди всех страхователей. Страхование рисков, сопутствующих производственной деятельности в сельском хозяйстве является одним из способов стабилизации доходов сельскохозяйственных товаропроизводителей. Специфика страхования в сельском хозяйстве состоит в том, что в этой отрасли процесс производства неразрывно связан с естественными процессами развития живых организмов - растений и животных, жизнедеятельность которых во многом зависит от природных явлений, а также использованием земли в качестве главного средства производства. Изучение опыта других стран показало, что государственная поддержка страхования эффективнее финансовой помощи, оказываемой товаропроизводителям в неблагоприятные годы в виде дополнительных кредитов, субсидий, зачетов, списаний, отсрочки и прямых денежных компенсаций. Научно обоснованная и эффективная организация страхового бизнеса в определенной мере способствует устойчивому развитию сельскохозяйственных предпринимательских структур во многих странах мира. В то же время вопросы определения страховых тарифов в зависимости от уровня рискованности земледелия, а также проблемы принятия решения о целесообразности страхования посевов в тех или иных условиях хозяйствования исследованы недостаточно полно. Дискуссионными и малоизученными остаются проблемы, связанные с необходимостью и механизмом государственного регулирования аграрного страхового рынка, имеющего свои особенности, обусловленные природными и экономическими условиями сельскохозяйственного производства [2, с. 4].

Выводы. Исходя из вышеизложенного, следует сделать вывод о том, что особенности административно-правового обеспечения развития аграрного сектора в Украине и Российской Федерации имеют как сходные, так и отличительные черты. Схожесть в регуляторной политике заключается в необходимости повышения стандартизации производства аграрной продукции в части безопасности производства, фитосанитарных норм и экологизации производства. Данная схожесть обусловлена стремлением указанных государств повысить продовольственную безопасность внутри стран, а так же нарастить экспортный потенциал, тем самым увеличить рентабельность отрасли и налоговые поступления.

Отличительными особенностями данного процесса считаем два основных аспекта: 1) разновекторность экспортной ориентации агропредприятий Украины и Российской Федерации; 2) механизмы административно-правового обеспечения экономического развития аграрного сектора. Первый аспект предполагает диаметральную противоположность рыночной ориентации в процессе экспортной деятельности: 
украинские агропредприятия ориентируются на рынок ЕC, что предусматривает имплементацию наднациональных норм и стандартов Евросоюза, российские же предприятия аграрного сектора во внешнеэкономической деятельности направлены рынок Таможенного союза, где повышение экспортной позиции агарной продукции так же предусматривает повышения стандартов качества. В данных процессах следствием являются особенности механизмов административно-правового обеспечения, которые в Украине построены на предписаниях проведения технической модернизации предприятий без гарантий государственной финансовой поддержки, а в Российской Федерации финансовая поддержка предприятий АПК (льготное кредитование, дотирование, субсидирование, налоговые каникулы) занимает важное место в государственной политике, что существенно ускоряет процесс технической модернизации. С другой стороны, украинские предприятия аграрного сектора постепенно получают доступ к рынкам Европы с более высокой покупательной способностью.

Учитывая описанные тенденции, предложенные механизмы и направления совершенствования государственного регулирования функционирования предприятий АПК в комплексе формируют более гибкий и в то же время юридически однозначный консолидированный механизм повышения рентабельности производства данного вида экономической деятельности в Украине и Российской Федерации в современных условиях государственного развития.

\section{Iuтepamypa:}

1. Угода про асоціацію між Україною, з однієї сторони, та Європейським Союзом, Європейським співтовариством з атомної енергії і їхніми державами-членами, з іншої сторони Угоду ратифіковано із заявою Законом № 1678-VII від 16 вересня 2014 p. URL: http://zakon3.rada.gov.ua/laws/show/984_011

2. Назаренко К.Н. Страхование производственных рисков в сельском хозяйстве. Дисс. канд. эконом. наук: 08.00.05. Воронеж, 2001. 156 с.

\section{Аннотация}

Козлова О. И. Экономическое развитие аграрного сектора: актуальные перспективы совершенствования законодательства. - Статья.

В данной статье исследованы направления государственного регулирования агропромышленного комплекса в Российской Федерации и Украине. Основной проблемой совершенствования государственного регулирования агропромышленного комплекса в Российской Федерации выступает разобщенность нормативно-правовой базы, что приводит к неэффективному регулированию отношений в данной сфере. В статье показан сравнительный анализ государственного регулирования АПК в Российской Федерации и Украине.

Ключевые слова: агропромышленный комплекс, сельское хозяйство, государственное регулирование, аграрная политика, аграрный экспорт.

\section{Анотація}

Козлова О. І. Економічний розвиток аграрного сектору: актуальні перспективи вдосконалення законодавства. - Стаття.

В даній статті досліджено напрями державного регулювання агропромислового комплексу в Російській Федерації та Україні. Основною проблемою вдосконалення державного регулювання агропромислового комплексу в Російській Федерації виступає роз'єднаність нормативно-правової бази, що призводить до неефективного регулювання відносин у даній сфері. У статті показаний порівняльний аналіз державного регулювання АПК в Російській Федерації та Україні.

Ключові слова: агропромисловий комплекс, сільське господарство, державне регулювання, аграрна політика, аграрний експорт. 


\section{Summary}

Kozlova O. I. Economic development of the agrarian sector: actual perspectives of improving legislation. - Article.

This article explores the directions of state regulation of the agro-industrial complex in the Russian Federation and Ukraine. The main problem of improving the state regulation of the agro-industrial complex in the Russian Federation is the disunity of the regulatory framework, which leads to inefficient regulation of relations in this area. The article shows a comparative analysis of the state regulation of the agro-industrial complex in the Russian Federation and Ukraine.

Key words: agro-industrial complex, agriculture, state regulation, agrarian policy, agrarian exports. 